\title{
Addition of Consortium of Lactic Acid Bacteria Inoculants Improved Fermentation Quality and Microbial Communities of Whole Corn Silage
}

\author{
Fugui Jiang $^{1 \dagger}$, Haijian Cheng ${ }^{1 \dagger}$, Qing Jin ${ }^{1}$, Chen Wei ${ }^{1}$, Guoping Zhang ${ }^{1}$, Zhaokun Zhang ${ }^{1}$, Wenzheng Su ${ }^{1}$, Guang Shi ${ }^{1}$ \\ and Enliang Song ${ }^{1,2^{*}}$ \\ ${ }^{1}$ Shandong Key Lab of Animal Disease Control and Breeding, Institute of Animal Science and Veterinary Medicine, Shandong \\ Academy of Agricultural Sciences, Sangyuan Road Number 8, Jinan 250100, P. R. China \\ ${ }^{2}$ College of Life Sciences, Shandong Normal University, East Wenhua Road Number 88, Jinan 250014, P. R. China \\ "For correspondence: enliangs@126.com \\ 'Contributed equally to this work and are co-first authors \\ Received 07 November 2020; Accepted 02 January 2021; Published 10 May 2021
}

\begin{abstract}
This study aimed to explore how a consortium of lactic acid bacteria (LAB) inoculants impacted fermentation quality and microbial communities of whole corn silage. Corn forage was chopped and ensiled with distilled water (CON) or a consortium of LAB inoculants $\left[1 \times 10^{6} \mathrm{cfu}\right.$ of Lactobacillus plantarum and $5 \times 10^{5} \mathrm{cfu}$ of Lactobacillus buchneri per gram of fresh material (FM)] for 2, 4, 7, 15, 30 and 60 days. The results showed that the dry matter (DM), neutral detergent fiber (NDF), and water-soluble carbohydrate (WSC) contents decreased following 60 days of ensiling. During the initial 7 days of ensiling, LAB silages showed a faster decrease in $\mathrm{pH}$ and rise in lactic acid content. The DM loss, ammonia- $\mathrm{N}$ concentration, and yeast count were lower in LAB silages than in CON silages during the ensiling process. The dominant phylum and genus in FM were Proteobacteria and Rosenbergiella, respectively. In both silage types, Lactobacillus was the genus present with the highest abundance. Interestingly, undesirable microorganisms, including Paenibacillus and Klebsiella, were significantly decreased in LAB silages. In conclusion, the addition of a consortium of LAB inoculants can enhance fermentation quality and reduce population of undesirable microorganisms in corn silage. (C) 2021 Friends Science Publishers
\end{abstract}

Keywords: Corn; Fermentation quality; Microbial community; Silage; Lactic acid bacteria

\section{Introduction}

Ensiling can effectively preserve forage crops (Dunière et al. 2013), and access to high-quality silage feed for ruminants is the goal of preparing silage. A wide variety of silage additives has been developed to enhance the quality of silages, including fermentation stimulants and inhibitors, chemicals, and enzymes (Muck et al. 2018). Among these, lactic acid bacteria (LAB) inoculant is one of the most used additives for preparing silage (Muck et al. 2018). The interaction between LAB inoculants and epiphytic microbial communities in fresh material (FM) is critical to the overall fermentation process, and the fermentation products of these microorganisms directly affect the silage quality (Xu et al. 2019). However, fermentation is a complex process regulated by myriad different microbes. Thus, profiling of the microbial community in ensiled forages might offer valuable insight into the development of LAB inoculants and regulation of fermentation.

Previous studies have mainly focused on the effect of
LAB inoculants on silage fermentation and animal production (Rossi and Dellaglio 2007; Muck et al. 2013; Li et al. 2015). A recent meta-analysis of 130 articles revealed that LAB inoculants can improve silage fermentation by reducing the butyric acid and ammoniacal nitrogen $\left(\mathrm{NH}_{3}-\mathrm{N}\right)$ levels and increasing the lactic acid concentrations (Oliveira et al. 2017). Furthermore, A recent metaanalysis of 31 lactating dairy cattle studies indicated that silage inoculated with $\mathrm{LAB}$ inoculants enhanced milk production (Oliveira et al. 2017). However, Muck et al. (2013) reported an improvement in silage characteristics owing to LAB inoculants but could not explain the magnitude of the increase in milk production. In another study, although inoculated silage increased animal productivity, the inoculants did not affect silage fermentation (Kung and Muck 2015). Ellis et al. (2016) suggested that these inconsistent results may be due to variations in microbial communities between silages and interactions with microbes in the rumen, implying that profiling of the silage microbial community might improve our understanding of silage formation.

To cite this paper: Jiang F, H Cheng, Q Jin, C Wei, G Zhang, Z Zhang, W Su, G Shi, E Song (2021). Addition of consortium of lactic acid bacteria inoculants improved fermentation quality and microbial communities of whole corn silage. Intl J Agric Biol 25:1213-1221 
Denaturing gradient gel electrophoresis ( $\mathrm{Li}$ and Nishino 2011), real-time PCR (Stevenson et al. 2006), and ribosomal intergenic spacer analysis (Brusetti et al. 2011), have been used to assess the microbial community in silages. However, these approaches offer limited insight regarding the overall properties of microbial communities. More recently, next-generation high-throughput sequencing technologies have been used to investigate microbial communities in many flower silver grass (Miscanthus floridulu (Labnll.) Warb) (Li et al. 2015), soybean (Glycine max Merr.) (Ni et al. 2017), corn stalk (Zhang et al. 2018) and corn silages (Keshri et al. 2018). However, climatic conditions of different regions affect the fermentation quality of corn silage by influencing microbial community (Guana et al. 2018). Therefore, it is valuable and worthwhile to combine microbial community and fermentation in local corn silage with silage chemical analysis. LAB inoculants used to improve the quality of silages can be divided into homofermentative and heterofermentative based on their fermentation pattern. Homofermentative LAB decrease silage $\mathrm{pH}$ during early ensiling stages by fermenting watersoluble carbohydrates (WSC) to lactic acid, which inhibits molds, yeasts, pathogenic bacteria, and other detrimental microbes, thus enhancing silage fermentation (Weinberg et al. 1993; Keshri et al. 2018). In contrast, heterofermentative LAB can convert lactic acid into acetic acid during later ensiling stages, thus improving the aerobic stability of silages during feeding out (Hu et al. 2009).

Thus, consortium of inoculants is commonly used in the production of silage to exploit the benefits of both homoand heterofermentative LABs (Muck et al. 2018). The most commonly used homo- and heterofermentative LABs are Lactobacillus plantarum and Lactobacillus buchneri, respectively (Elferink et al. 2001; Koc et al. 2017; Blajman et al. 2018). Therefore, the objective of this study was thus to understand how the consortium of $L$. plantarum and $L$. buchneri affect fermentation products during ensiling in corn silage and further to investigate the variation in microbial community after ensiling using Illumina MiSeq sequencing.

\section{Materials and Methods}

\section{Silage preparation}

A corn hybrid (Denghai 605; Shandong Denghai Seeds Co., Ltd., Shandong, China) was planted on July 12, 2018 in the experimental field at Shandong Academy of Agricultural Sciences $\left(117^{\circ} 58^{\prime} \mathrm{E}, 37^{\circ} 63^{\prime} \mathrm{N}\right)$. The crop was harvested on September 16, 2018 and cut to $20 \mathrm{~mm}$ long segments using a chopper (FS-690; Zili, Guangdong, China).

\section{Experimental details}

Chopped forage was mixed together prior to equal division into portions for the following two treatments: distilled water $(\mathrm{CON})$ and consortium of $\mathrm{LAB}$ inoculants (LAB).
The consortium of LAB inoculants was applied at $1 \times 10^{6}$ colony-forming units (cfu) of L. plantarum and $5 \times 10^{5} \mathrm{cfu}$ of $L$. buchneri per gram of fresh material (FM) by mixing 5 $\mathrm{mL}$ of L. plantarum $\left(10^{9} \mathrm{cfu} / \mathrm{mL}\right.$ cell suspension) with $5 \mathrm{~mL}$ of L. buchneri $\left(5 \times 10^{8} \mathrm{cfu} / \mathrm{mL}\right.$ cell suspension $)$ and spraying the suspension on $5 \mathrm{~kg}$ of chopped corn. The two LAB species were isolated from whole-plant corn silage and identified using approaches previously detailed by Zhang et al. (2016). These two LABs were selected based on their rapid rates of growth and significant acid production capabilities. The L. plantarum and L. buchneri strains used herein were closely related to L. plantarum and L. buchneri, with 100 and $99.79 \%$ 16S rDNA gene sequence identity, respectively. Sequences for the $L$. plantarum and $L$. buchneri strains used in the present study were deposited in GenBank with the accession numbers MN701197 and MN700263, respectively. Approximately $1000 \mathrm{~g}$ of preensiled sample was placed into plastic bag $(20 \mathrm{~cm} \times 30 \mathrm{~cm}$; Deli Group Co., Ltd., Shanghai, China), which was vacuum sealed (Deli 14886; Deli Group Co., Ltd.). Experiment was laid out following completely randomized design (CRD) and a total of 60 bags ( 2 treatments $\times 6$ ensiling periods $\times 5$ replicates) were made and maintained at the ambient temperature $\left(23-28^{\circ} \mathrm{C}\right)$. Five bags for each treatment were opened for analyzing microbial community, $\mathrm{pH}$ value and organic acid contents after 2, 4, 7, 15, 30, and 60 days of ensiling, respectively.

\section{Microbial and chemical analyses}

Bags were unsealed on a clean workspace, after which $20 \mathrm{~g}$ of silage sample was mixed with $180 \mathrm{~mL}$ of sterile water, and the sample then underwent serial dilution from $10^{-1}$ to $10^{-9}$. Numbers of LAB and Clostridia were determined using the plate count method on de Man, Rogosa, and Sharpe agar (CM361; Oxoid Ltd., Waltham, MA, USA) and Clostridia Count Agar (11045; Qingdao Rishui Biotechnologies Co., Ltd., Qingdao, China), respectively. The plates were anaerobically incubated at $37^{\circ} \mathrm{C}$ for $48 \mathrm{~h}$ using AnaeroPack-Anaero (Mitsubishi Gas Chemical Co., Inc., Tokyo, Japan). The yeast count was determined on potato dextrose agar (HB0233-12; Qingdao Hope Bio-Technology Co., Ltd., Qingdao, China) following a $30^{\circ} \mathrm{C}$ incubation for $48 \mathrm{~h}$. Colony counts is presented as the number of viable microorganisms in $\mathrm{cfu} / \mathrm{g} \mathrm{FM}$.

To determine the $\mathrm{pH}$ and organic acid content, $180 \mathrm{~mL}$ of sterile water was mixed with $20 \mathrm{~g}$ of fresh samples for 1 minute in a blender, followed by sample passage through a $0.22 \mu \mathrm{m}$ membrane filter. Hundred milliliters of sample were used to immediately determine the $\mathrm{pH}$ using a glass electrode $\mathrm{pH}$ meter (HI991000; Hanna Instruments, RI, USA). Five milliliters of sample were stored in $1 \mathrm{~mL}$ of $25 \%(\mathrm{w} / \mathrm{v})$ metaphosphoric acid at $-20^{\circ} \mathrm{C}$ to determine the organic acid content. Five milliliters of sample were stored in $1 \mathrm{~mL}$ of $1 \% \mathrm{H}_{2} \mathrm{SO}_{4}$ at $-20^{\circ} \mathrm{C}$ to measure $\mathrm{NH}_{3}-\mathrm{N}$ levels. The content of organic acids (lactic, acetic, butyric, and 
propionic acids) was measured via HPLC using a Shodex RSpak KC-811S-DVB gel C column $(8.0 \mathrm{~mm} \times 30 \mathrm{~cm}$; Shimadzu, Tokyo, Japan), under the following conditions: oven temperature, $50^{\circ} \mathrm{C}$; mobile phase, $3 \mathrm{mmol} / \mathrm{L} \mathrm{HClO}_{4}$; flow rate, $1.0 \mathrm{~mL} / \mathrm{min}$; injection volume, $5 \mathrm{~mL}$; and detector, SPD-M10AVP (210 nm). The $\mathrm{NH}_{3}-\mathrm{N}$ content was assessed via phenol-hypochlorite assay as previously detailed in a study conducted by Weatherburn (1967).

A $65^{\circ} \mathrm{C}$ forced air oven was used to dry samples over a $48 \mathrm{~h}$ period, after which a Wiley mill (A. H. Thomas, PA) was used to grind sampled through a $1-\mathrm{mm}$ screen. The analytical dry matter (DM) content was analyzed by weighing the sample after drying at $105^{\circ} \mathrm{C}$ for $3 \mathrm{~h}$. Crude protein $(\mathrm{CP})$, ether extract (EE), and acid detergent lignin (ADL) were measured via standardized protocols produced by the Association of Official Analytical Chemists (AOAC 1990). Levels of both neutral detergent fiber (NDF) and acid detergent fiber (ADF) were determined using the methods reported by Soest et al. (1991), with NDF analyses relying on amylase and sodium sulfite. The WSC content was measured via the anthrone method (Murphy 1958). DM recovery was calculated based on the initial and final forage weights and the DM contents of the fresh and ensiled forage.

\section{Microbial DNA extraction and PCR amplification}

Approximately $50 \mathrm{~g}$ per silage sample was immediately frozen with liquid nitrogen. A subsample of $5 \mathrm{~g}$ was ballmilled at $25-28^{\circ} \mathrm{C}$ for $1 \mathrm{~min}$, and an EZNA Soil DNA kit (Omega Bio-tek, GA, USA) was used to isolate microbial DNA. DNA purity and quality were checked using a UV-vis spectrophotometer (NanoDrop 2000; Thermo Scientific, USA) and by $1 \%$ agarose gel electrophoresis, respectively.

The 16s rRNA V3-V4 hypervariable regions were amplified using the $338 \mathrm{~F}$ (5'ACTCCTACGGGAGGCAGCAG-3') and 806R (5'GGACTACHVGGGTWTCTAAT-3') primers in a GeneAmp 9700 thermocycler system (ABI, USA). Triplicate reactions were conducted, with each reaction having a $20 \mu \mathrm{L}$ total volume containing $10 \mathrm{ng}$ of DNA along with $4 \mu \mathrm{L}$ of $5 \times$ FastPfu Buffer, $0.4 \mu \mathrm{L}$ of FastPfu Polymerase, $2 \mu \mathrm{L}$ of $2.5 \mathrm{mM}$ dNTPs, and $0.8 \mu \mathrm{L}$ of the forward and reverse primers $(5 \mu M)$. Thermocycler conditions were: $3 \mathrm{~min}$ at $95^{\circ} \mathrm{C} ; 27$ cycles of $95^{\circ} \mathrm{C}$ for $30 \mathrm{~s}$, $55^{\circ} \mathrm{C}$ for $30 \mathrm{~s}, 72^{\circ} \mathrm{C}$ for $45 \mathrm{~s}$; and $10 \mathrm{~min}$ at $72^{\circ} \mathrm{C}$. Next, $2 \%$ agarose gel electrophoresis and an AxyPrep DNA Gel Extraction Kit (Axygen Biosciences, CA, USA) were used to isolate PCR products, while a QuantiFluor ${ }^{\mathrm{TM}_{-} \mathrm{ST}}$ (Promega, USA) was used for their quantification.

\section{Sequencing and microbial diversity analysis}

Equimolar concentrations of PCR amplicons were pooled prior to paired-end sequencing $(2 \times 300)$ on an Illumina MiSeq platform (Illumina, San Diego, CA, USA). The raw data were quality-filtered using Trimmomatic and merged with FLASH (Magoč and Salzberg 2011) based upon the criteria that follow: (i) all sequences were truncated at any ste that had a $<20$ average quality score over a sliding $50 \mathrm{bp}$ window; (ii) any reads were removed if they contained ambiguous bases or were exact matches to primer sequences with up to a two-nucleotide mismatch; and (iii) any sequences that had $>10$ bp of overlap were merged. UPARSE (version 7.1) was used for operational taxonomic unit (OTU) clustering based upon a 97\% similarity threshold, with UCHIME (Edgar 2013) used for chimeric sequence identification and removal. To analyze the taxonomy, the Silva (SSU123) 16S rRNA database was used for alignment of 16S rRNA sequences based upon the RDP classifier algorithm (version 2.2) (Wang et al. 2007) with a $70 \%$ confidence threshold. Alpha diversity indices (Shannon index, Chao richness estimator, and Good's coverage estimator) and beta diversity indices were determined using QIIME (v. 1.7.0). R (v. 2.15.3) was used for principal component analysis (PCA).

\section{Statistical analysis}

The data of this study were analyzed using one-way Analysis of Variance (ANOVA) analysis and Duncan's multiple range tests based on the general linear model procedure (PROC GLM) of SAS (version 9.1, SAS Institute Inc., Cary, NC, USA). All data are presented as least-squares mean. The effects of the factors were considered significant at $P \leq 0.05$ and trends were recognized at $0.05<P \leq 0.10$.

\section{Results}

\section{Chemical composition and microbial population before and after ensiling}

Chemical composition and microbial count as determined by plate culture prior to and after 60 days of ensiling is shown in Table 1. Relative to values within the FM, DM, NDF, and WSC levels were reduced after 60 days of ensiling $(P<$ 0.05), while the $\mathrm{CP}, \mathrm{ADF}, \mathrm{ADL}$ and EE were similar among the treatments $(P>0.10)$. The DM of LAB silages was higher than that of $\mathrm{CON}$ silages $(P<0.05)$, whereas other chemical parameters were similar between LAB and CON silages $(P>0.10)$. Compared with those in the FM, the LAB count was increased, and yeast and Clostridia counts were decreased after 60 days of ensiling $(P<0.01)$. The LAB count was higher, and the yeast count was lower in LAB silages than in CON silages, whereas the Clostridia count was similar between CON and LAB silages.

Effect of LAB inoculants on DM loss, pH, and the microbial population in corn silages

As shown in Fig. 1, following 60 days of ensiling, the DM loss from LAB silage was lower than from CON silage. The $\mathrm{pH}$ of CON and LAB silages decreased during the ensiling 
process (Fig. 2), but LAB silage showed a fast $\mathrm{pH}$ decrease from the beginning of ensiling and thus, its $\mathrm{pH}$ was lower than that of CON during the initial 7 days of ensiling $(P<$ $0.05)$. The populations of LAB and yeast in all treatments increased initially, and then decreased during the ensiling process, but LAB silage had a higher LAB count and lower yeast count than $\mathrm{CON}$ silage throughout the ensiling process $(P<0.05)$. The Clostridia count decreased with increasing ensiling time in all treatments $(P<0.05)$. The Clostridia count in LAB silage was lower than that in CON silage during the initial 7 days of ensiling, while prolonged ensiling time induced no other changes.

\section{Impact of LAB inoculants on the content of organic acids and $\mathrm{NH}_{3}-\mathrm{N} /$ total nitrogen \\ (TN) in corn silages}

As shown in Fig. 3, the lactic acid content was higher in LAB silages than in CON silages during the first 15 days of ensiling $(P<0.05)$, whereas no difference was observed with prolonged ensiling time $(P>0.05)$. The acetic acid content was similar between $\mathrm{CON}$ and $\mathrm{LAB}$ silages during the first 15 days of ensiling, but it was higher in LAB silage than in CON silage after 30 days of ensiling. The lactic to acetic acid ratio in LAB silages was higher at 2 days of ensiling and lower after 60 days than that in $\mathrm{CON}$ silages $(P<0.05)$. The $\mathrm{NH}_{3}-\mathrm{N}$ to $\mathrm{TN}$ ratio was higher in CON silages than in LAB silages during the entire ensiling period (Fig. 3).

\section{Effect of LAB inoculants on bacterial communities following 60 days of ensiling}

Bacterial alpha diversity index values were assessed (Table 2). Good's coverage was approximately 0.99 for all treatments, indicating that most of the bacteria were detected. The number of OTUs was increased after 60 days of ensiling when compared to that in the FM; however, it did not significantly differ between $\mathrm{CON}$ and LAB silages. Other richness bacterial community indices, Chao and Shannon, showed trends similar to that of the OTUs.

Shifts in the bacterial community under different treatments can be demonstrated by PCA. As shown in Fig. 4, principal components 1 and 2 explained 50.84 and $33.98 \%$ of the total variance, respectively. The FM was well separated from the silage samples and CON silages were well separated from LAB silages.

Phylum and genus level bacterial community structures of pre-ensiled and ensiled samples are presented in Fig. 5 and 6, respectively. The dominant phylum in FM was Proteobacteria (69.94-98.51\%), whereas that in silages after 60 days of ensiling was Firmicutes (66.1295.15\%; Supplementary Table S1). The dominant genera in FM were Rosenbergiella, Klebsiella, and Pantoea, with relative abundances of 9.7-58.5\%, 11.3 $29.9 \%$, and $8.8-20.9 \%$, respectively (Supplementary Table S2). However, the abundances of these genera were
Table 1: Chemical composition and microbial count determined by plate culture before and after 60 days of ensiling

\begin{tabular}{|c|c|c|c|c|c|}
\hline \multicolumn{6}{|c|}{ Treatments } \\
\hline Item & $\mathrm{FM}$ & $\mathrm{CON}$ & LAB & SEM & $P$ value \\
\hline $\mathrm{DM}(\% \mathrm{FM})$ & $32.74^{\mathrm{a}}$ & $29.78^{\mathrm{c}}$ & $30.66^{\mathrm{b}}$ & 0.34 & $<0.01$ \\
\hline $\mathrm{CP}(\% \mathrm{DM})$ & 8.28 & 8.33 & 8.28 & 0.03 & 0.81 \\
\hline NDF (\% DM) & $39.86^{\mathrm{a}}$ & $38.65^{\mathrm{ab}}$ & $37.98^{\mathrm{b}}$ & 0.32 & 0.04 \\
\hline $\mathrm{ADF}(\% \mathrm{DM})$ & 21.18 & 21.32 & 21.58 & 0.20 & 0.74 \\
\hline $\operatorname{ADL}(\% \mathrm{DM})$ & 2.78 & 2.53 & 2.57 & 0.07 & 0.36 \\
\hline $\mathrm{EE}(\% \mathrm{DM})$ & 3.08 & 2.93 & 3.03 & 0.09 & 0.83 \\
\hline WSC (\% DM) & $10.61^{\mathrm{a}}$ & $4.66^{\mathrm{b}}$ & $4.50^{\mathrm{b}}$ & 0.78 & $<0.01$ \\
\hline LAB $(\log \mathrm{cfu} / \mathrm{g}$ FM $)$ & $5.47^{\mathrm{c}}$ & $6.27^{\mathrm{b}}$ & $6.78^{\mathrm{a}}$ & 0.16 & $<0.01$ \\
\hline Yeast (log cfu/g FM) & $6.73^{\mathrm{a}}$ & $4.52^{\mathrm{b}}$ & $4.11^{\mathrm{c}}$ & 0.29 & $<0.01$ \\
\hline Clostridia (log cfu/g FM) & $8.40^{\mathrm{a}}$ & $3.03^{\mathrm{b}}$ & $2.91^{\mathrm{b}}$ & 0.62 & $<0.01$ \\
\hline
\end{tabular}

Table 2: Alpha diversity indices of bacterial diversity in fresh material and silages after 60 days of ensiling

\begin{tabular}{llllll}
\hline & Reads & OTUs & Shannon & Chao1 & Good's coverage \\
\hline FM & 30772 & $105.20^{\mathrm{b}}$ & $1.94^{\mathrm{b}}$ & $142.88^{\mathrm{b}}$ & 0.99 \\
CON & 30772 & $209.40^{\mathrm{a}}$ & $2.23^{\mathrm{a}}$ & $231.46^{\mathrm{a}}$ & 0.99 \\
LAB & 30772 & $202.20^{\mathrm{a}}$ & $2.20^{\mathrm{a}}$ & $217.73^{\mathrm{a}}$ & 0.99 \\
\hline \multicolumn{7}{l}{ Values in the same row with different superscript letters differ at $P<0.05$} \\
FM, fresh material; CON, corn silage ensiled without inoculant; LAB, corn silage \\
ensiled with consortium of inoculants containing Lactobacillus plantarum and \\
Lactobacillus buchneri
\end{tabular}

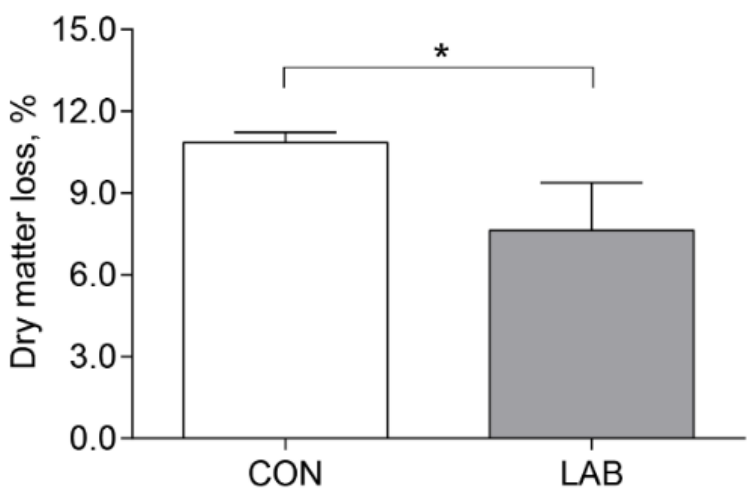

Fig. 1: Effect of consortium of LAB inoculants on dry matter loss from corn silage after 60 days of ensiling

$\mathrm{CON}$, corn silage ensiled without inoculants; LAB, corn silage ensiled with consortium of inoculants containing Lactobacillus plantarum and Lactobacillus buchneri; * indicates that the dry matter loss between $\mathrm{CON}$ and LAB silages differed at $P<0.05$

significantly reduced after ensiling. After ensiling, Lactobacillus, Paenibacillus, and Klebsiella were the dominant bacteria, with relative abundances of $45.7-86.5 \%$, $2.5-24.4 \%$, and $1.7-9.3 \%$, respectively.

As shown in Fig. 7, differences in the bacterial microbiota among treatments and the specific bacterial microbiota in each treatment were analyzed using the linear discriminant analysis (LDA) effect size method (LDA score > 4.0). Paenibacillus, Klebsiella, and Leuconostoc, which were abundant in CON silages, and Lactobacillus, which was abundant in LAB silages, were the primary genera resulting in differences between $\mathrm{CON}$ and $\mathrm{LAB}$ silages. 

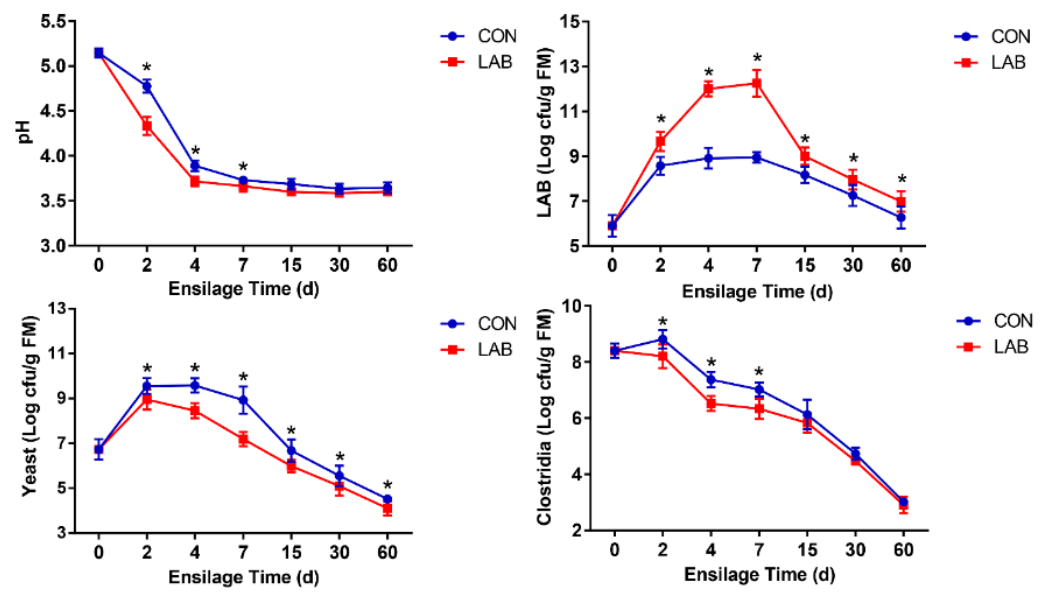

Fig. 2: Changes in $\mathrm{pH}$ and microbial population during the ensiling of corn silage $* P<0.05$ vs. CON
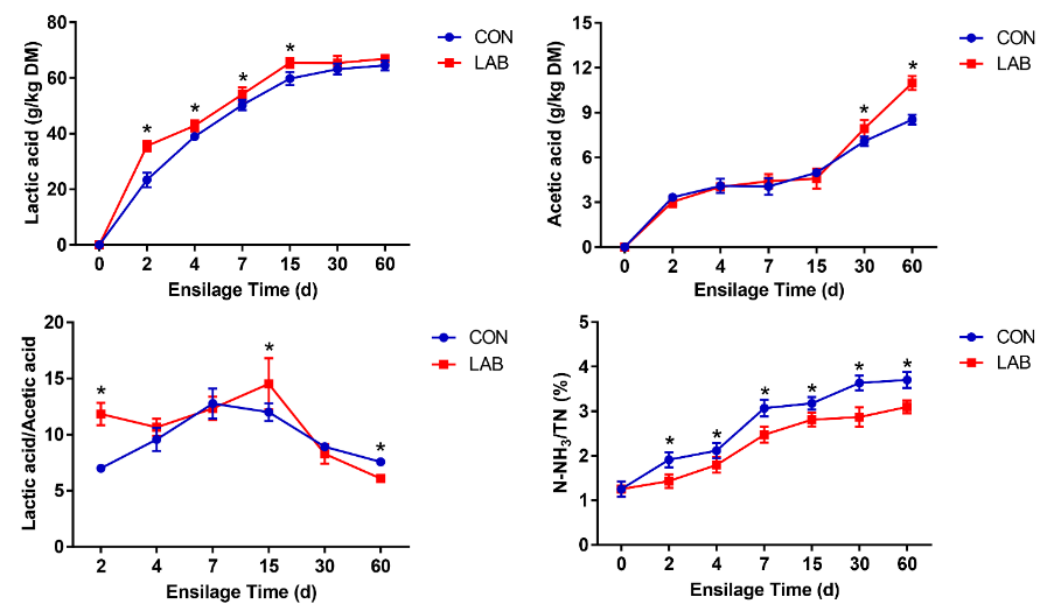

Fig. 3: Changes in organic acid and $\mathrm{NH}_{3}-\mathrm{N} / \mathrm{TN}$ contents during the ensiling of corn silage $* P<0.05$ vs. CON

\section{Discussion}

The LAB cell number and WSC content in FM are considered crucial factors in determining the adequacy of silage fermentation. A LAB cell count of more than $10^{5}$ cfu/g FM (Cai et al. 1998) and a WSC content higher than 6\% DM (Woolford and Pahlow 1984) have been reported to be adequate for ensuring acceptable fermentation quality. In this regard, the LAB count and content of WSC in the FM were sufficient for adequate fermentation during ensiling. This might explain the similar chemical compositions of LAB and CON silages. As expected, the DM and WSC content decreased after ensiling, mainly because plant cells continue to consume the oxygen entrapped in the silage material during early ensiling stages and then, microorganisms ferment the WSC mainly into lactic acid. The decreased NDF content in silages compared with FM may be the result of hydrolysis of the digestible cell wall fraction by organic acids produced during ensiling (Larsen et al. 2017).
One of the purposes of using silage inoculants in silage production is to reduce the loss of DM. One limitation of using L. buchneri, an obligate heterofermentative LAB, as a silage inoculant is that it can result in higher DM loss. Kleinschmit and Kung (2006) reported that L. buchneri treatment of silages alone led to higher DM loss than that in non-treated silages as indicated by a meta-analysis. However, in the present study, inoculation of $L$. buchneri combined with the homofermentative L. plantarum reduced DM loss when compared with that in CON silages. Driehuis et al. (2001) and Arriola et al. (2011) have reported similar results. These results indicate that inoculants that combine homo- and heterofermentative LABs can exploit the benefits of both types of inoculants in silages.

The $\mathrm{pH}$ fluctuation is a key indicator of microbial activity and of the process of silage fermentation (McDonald et al. 1991). Consistent with findings in previous studies (Desta et al. 2016; Ni et al. 2017), we found that $\mathrm{pH}$ fell mainly during the first 7 days of ensiling. This decreased $\mathrm{pH}$ observed in CON and LAB silages can 


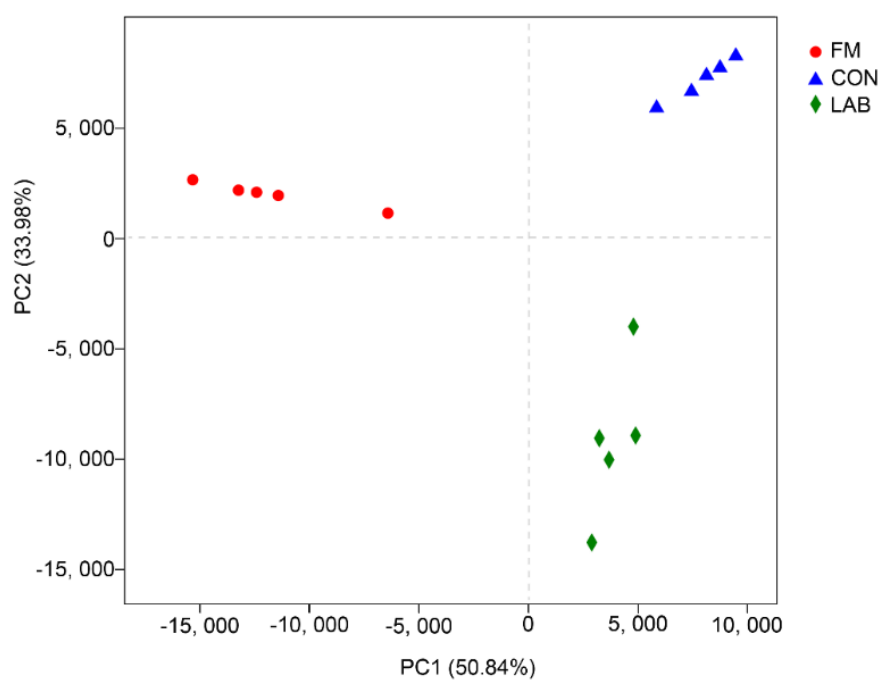

Fig. 4: Principle component analysis (PCA) of samples

$\mathrm{PC} 1$, principal component 1; PC2, principal component 2; FM, fresh material; CON, corn silage ensiled without inoculants; LAB, corn silage ensiled with consortium of inoculants containing Lactobacillus plantarum and Lactobacillus buchneri

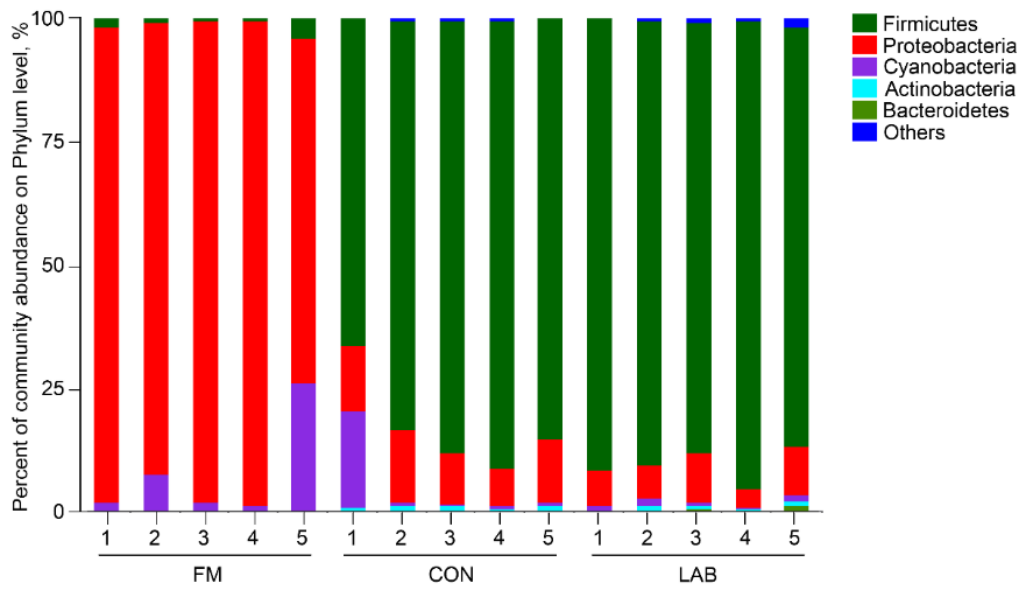

Fig. 5: Relative abundances of bacteria at the phylum level

FM, fresh material; CON, corn silage ensiled without inoculants; LAB, corn silage ensiled with consortium of inoculants containing Lactobacillus plantarum and Lactobacillus buchneri

be mainly attributed to the increased lactic acid content, which is the main organic acid throughout the ensiling process and in the final silage. In the present study, the lactic acid content considerably rose over the initial 15 days of ensiling, and then plateaued. However, Ni et al. (2017) reported plateauing on days 7 and 14 in soybean silage without and with molasses (2\% FM), respectively. Similarly, Desta et al. (2016) reported plateauing on days 7 and 60 in Napier grass silage without and with molasses (4\% FM), respectively. The discrepancy probably is due to differences in WSC content and buffering capacity among these treatments. The WSC content in corn silage was higher than that in soybean silage and Napier grass, resulting in more soluble carbohydrate supply for LAB metabolism. Meanwhile, the added molasses could compensate for the lack of soluble carbohydrates in soybean silage and Napier grass.
The rapid decrease in $\mathrm{pH}$ and increase in lactic acid content in LAB silages observed herein can be mainly linked to $L$. plantarum activity, which can minimize the activity of other microorganisms, such as enterobacteria and bacilli, in the early phase of fermentation (Muck 2010). Herein, acetic acid levels were higher in LAB silages relative to CON silages following 30 days of ensiling, implying that $L$. buchneri mediated anaerobic lactic to acetic acid conversion. Similarly, Driehuis et al. (1999) applied $L$. buchneri at $5 \times 10^{5} \mathrm{cfu} / \mathrm{g}$ to corn silage and noted a difference in the acetic acid content between treated and non-treated materials on day 28. Furthermore, the higher content of acetic acid in LAB silages in this study implied an improvement in the aerobic stability of the silages (Muck et al. 2018). As expected, the $\mathrm{NH}_{3}-\mathrm{N}$ content was lower in LAB silages than in CON silages in this study. A recent meta-analysis of 130 articles reported similar results 


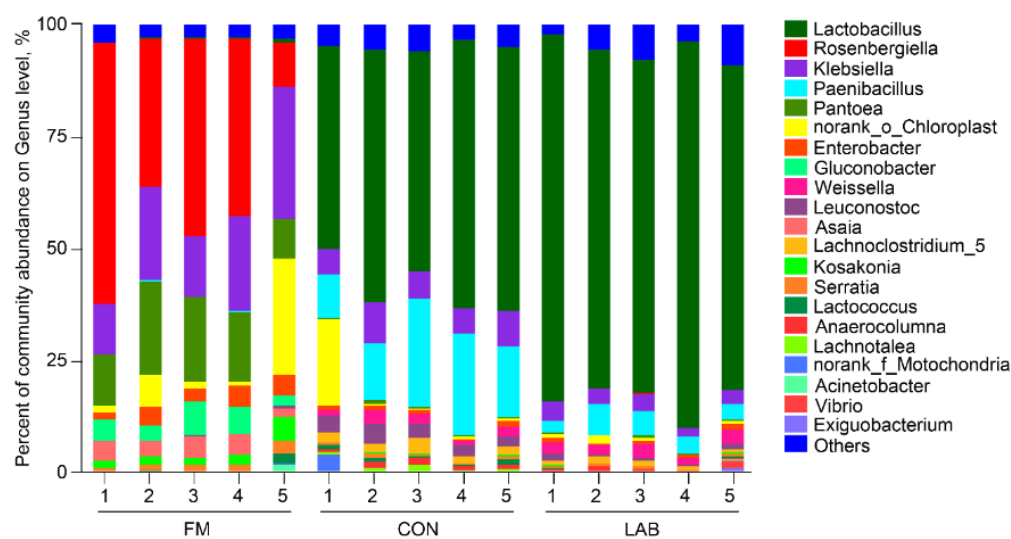

Fig. 6: Relative abundances of bacteria at the genus level

FM, fresh material; CON, corn silage ensiled without inoculants; LAB, corn silage ensiled with consortium of inoculants containing Lactobacillus plantarum and Lactobacillus buchneri
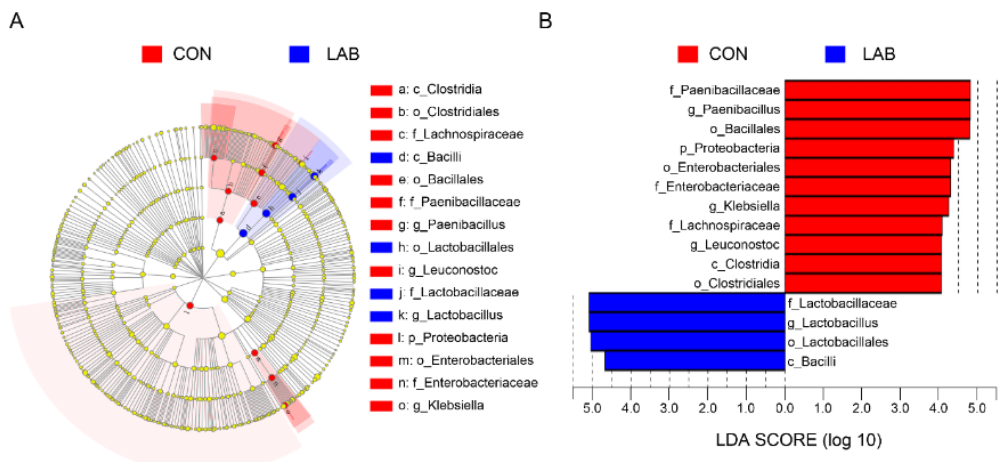

Fig. 7: Changes in the microbial community in LAB vs. CON silages as determined by the linear discriminant analysis effect size method (A) Cladogram of significantly differential bacteria. Differences are represented in the color of the most abundant taxa. (B) Histogram of the LDA scores for differentially abundant features among treatments. The threshold on the logarithmic LDA score for discriminative features was set to 4.0

(Oliveira et al. 2017). Yeasts are undesirable in silage because they cause aerobic deterioration either during the aerobic phase in the beginning of ensiling or during the unloading phase and thus reduce the nutritional value of silage. The yeast count increased on day 2 of ensiling, which might be due to the oxygen entrapped in the silage as the aerobic yeasts develop until the oxygen is exhausted (Dunière et al. 2013). After 2 days of ensiling, the yeast count decreased, mainly because of the decrease in $\mathrm{pH}(\mathrm{Ni}$ et al. 2017). We found that $L A B$ silages had lower yeast and Clostridia counts and $\mathrm{NH}_{3}-\mathrm{N}$ content, but higher lactic acid and acetic acid contents relative to $\mathrm{CON}$ silages during the process of ensiling. This suggests that the addition of LAB improves the fermentation quality of silages.

Consistent with past findings (Ni et al. 2017; Zhao et al. 2017; Wang et al. 2018), the bacterial community was more diverse after ensiling. Proteobacteria was the dominant phylum in FM in this study. However, relative Firmicutes abundance rose during the ensiling process such that it became the predominant phylum after ensiling. Similar results had been reported in studies on silages of other materials, such as Moringa oleifera leaf (Wang et al. 2018), Medicago (Bao et al. 2016), and grass silages (Eikmeyer $e t$ al. 2013). We found that dominant genera in FM were mostly undesirable bacteria, such as Rosenbergiella, Klebsiella, Pantoea, and Enterobacter, which can ferment lactic acid to thereby drive nutrition loss (Ridwan et al. 2015). However, relative levels of these undesirable bacteria were substantially decreased after ensiling. This might be due to increasing lactic acid content accompanied by decreasing $\mathrm{pH}$, resulting in growth inhibition of these undesirable microorganisms.

Lactobacillus (54.0\%), Paenibacillus (17.1\%), and Klebsiella (6.8\%) were the dominant genera in CON silages. Paenibacillus is a gram-positive, facultative anaerobic, spore-forming bacterium. It has been detected in grass (Giffel et al. 2002) and corn (Rossi and Dellaglio 2007) silages. Paenibacillus spp. is undesirable microorganisms in silages. Paenibacillus in silages is one of the primary contamination sources of spore formers at the farm level (Coorevits et al. 2008), and its spores are heatresistant and thus can survive pasteurization (Borreani et al. 2013). Spore formers can contaminate milk via the cow's diet and then produce toxins and spoilage enzymes, exerting harmful effects on food safety and product quality (Ivy et al. 2012). Pahlow et al. (2003) reported that the Paenibacillus spore count in silage determines the number of endospores that leave the animal and resultant milk contamination 
magnitude. Therefore, silage additives that can directly inhibit or reduce the Paenibacillus count in silages should be developed in future. Klebsiella spp. is gram-negative, facultative anaerobes that can cause animal diseases and therefore also are undesirable in silages. Herein, relative Lactobacillus abundance in LAB silages increased to $78.2 \%$, whereas that of Paenibacillus and Klebsiella decreased to 4.5 and $3.3 \%$, respectively. These results corroborate that the addition of $L$. plantarum and $L$. buchneri improves silage quality.

\section{Conclusion}

Addition of a consortium of $\mathrm{LAB}$ inoculants led to a rapid $\mathrm{pH}$ reduction and elevated lactic acid contents in the early phase of ensiling. Following 60 days of ensiling, these LAB inoculants improved the LAB count and acetic acid content and decrease the yeast count and $\mathrm{NH}_{3}-\mathrm{N}$ content. Moreover, it enhanced the abundance of desirable Lactobacillus while preventing undesirable Paenibacillus growth and reducing DM loss. In conclusion, addition of consortium of LAB inoculants addition can improve the fermentation quality and decrease undesirable microorganisms in corn silage.

\section{Acknowledgments}

This research was financially supported by the Shandong Provincial Natural Science Foundation, China (ZR2019BC086), Agricultural Science and Technology Innovation Project of Shandong Academy of Agricultural Sciences (CXGC2018E10) and China Agriculture Research System (CARS-37). We would like to thank Edit age (www.editage.cn) for English language editing.

\section{Author Contributions}

FJ, HC and ES planned the experiments, QJ and CW interpreted the results, GZ, ZZ, WS and GS made the write up and FJ statistically analyzed the data and made illustrations.

\section{Conflicts of Interest}

The authors declare that the research was conducted in the absence of any commercial or financial relationships that could be construed as a potential conflict of interest.

\section{Ethics Approval}

Not Applicable.

\section{Data Availability}

The data will be available upon reasonable requests to the corresponding author.

\section{References}

Arriola KG, SC Kim, AT Adesogan (2011). Effect of applying inoculants with heterolactic or homolactic and heterolactic bacteria on the fermentation and quality of corn silage. J Dairy Sci 94:1511-1516

Association of Official Analytical Chemists (1990). Official Methods of Analysis, $15^{\text {th }}$ edn. Arlington, Virginia, USA

Bao W, Z Mi, H Xu, Y Zheng, LY Kwok, H Zhang, W Zhang (2016). Assessing quality of Medicago sativa silage by monitoring bacterial composition with single molecule, real-time sequencing technology and various physiological parameters. Sci Rep 6; Article 28358

Blajman JE, RB Páez, CG Vinderola, MS Lingua, ML Signorini (2018). A meta-analysis on the effectiveness of homofermentative and heterofermentative lactic acid bacteria for corn silage. $J$ Appl Microbiol 125:1655-1669

Borreani G, P Dolci, E Tabacco, L Cocolin (2013). Aerobic deterioration stimulates outgrowth of spore-forming Paenibacillus in corn silage stored under oxygen-barrier or polyethylene films. J Dairy Sci 96:5206-5216

Brusetti L, E Crotti, A Tamburini, D Cittaro, V Garavaglia, E Rolli, C Sorlini, D Daffonchio, S Borin (2011). Influence of transgenic Bt176 and non-transgenic corn silage on the structure of rumen bacteria communities. Ann Microbiol 61:925-930

Cai Y, Y Benno, M Ogawa, S Ohmomo, S Kumai, K Nakase (1998). Influence of Lactobacillus spp. from an inoculant and of Weissella and Leuconostoc spp. from forage crops on silage fermentation. Appl Environ Microbiol 64:2982-2987

Coorevits A, VD Jonghe, J Vandroemme, R Reekmans, J Heyrman, W Messens, PD Vos, M Heyndrickx (2008). Comparative analysis of the diversity of aerobic spore-forming bacteria in raw milk from organic and conventional dairy farms. Syst Appl Microbiol 31:126140

Desta ST, XJ Yuan, JF Li, T Shao (2016). Ensiling characteristics, structural and nonstructural carbohydrate composition and enzymic digestibility of Napier grass ensiled with additives. Bioresour Technol 221:447-454

Driehuis F, SJWH Oude Elferink, PGV Wikselaar (2001). Fermentation characteristics and aerobic stability of grass silage inoculated with Lactobacillus buchneri, with or without homofermentative lactic acid bacteria. Grass Forage Sci 56:330-343

Driehuis F, SJWHO Elferink, SF Spoelstra (1999). Anaerobic lactic acid degradation during ensilage of whole-crop maize inoculated with Lactobacillus buchneri inhibits yeast growth and improves aerobic stability. J Appl Microbiol 87:583-594

Dunièrea L, J Sindoub, F Chaucheyras-Durand, I Chevallierd, D ThévenotSergenteta (2013). Silage processing and strategies to prevent persistence of undesirable microorganisms. Anim Feed Sci Technol $182: 1-15$

Edgar RC (2013). UPARSE: highly accurate OTU sequences from microbial amplicon reads. Nat Meth 10:996-998

Eikmeyer FG, P Köfinger, A Poschenel, S Jünemann, M Zakrzewski, S Heinl, E Mayrhuber, R Grabherr, A Pühler, H Schwab, A Schlüter (2013). Metagenome analyses reveal the influence of the inoculant Lactobacillus buchneri $\mathrm{CD} 034$ on the microbial community involved in grass ensiling. J Biotechnol 167:334-343

Elferink SJWHO, J Krooneman, JC Gottschal, SF Spoelstra, F Faber, F Driehuis (2001). Anaerobic conversion of lactic acid to acetic acid and 1, 2-propanediol by Lactobacillus buchneri. Appl Environ Microbiol 67:125-132

Ellis JL, IK Hindrichsen, G Klop, RD Kinley, N Milora, A Bannink, J Dijkstra (2016). Effects of lactic acid bacteria silage inoculation on methane emission and productivity of Holstein Friesian dairy cattle. J Dairy Sci 99:7159-7174

Giffel MCT, A Wagendorp, A Herrewegh, F Driehuis (2002). Bacterial spores in silage and raw milk. Anton Leeuwen 81:625-630

Guana H, Y Yan, X Li, X Li, Y Shuai, G Feng, Q Ran, Y Cai, Y Li, X Zhang (2018). Microbial communities and natural fermentation of corn silages prepared with farm bunker-silo in Southwest China. Bioresour Technol 265:282-290 
Hu W, RJ Schmidt, EE McDonell, CM Klingerman, JL Kung (2009). The effect of Lactobacillus buchneri 40788 or Lactobacillus plantarum MTD $_{-1}$ on the fermentation and aerobic stability of corn silages ensiled at two dry matter contents. J Dairy Sci 92:3907-3914

Ivy RA, ML Ranieri, NH Martin, HCD Bakker, BM Xavier, M Wiedmann, KJ Boor (2012). Identification and characterization of psychrotolerant sporeformers associated with fluid milk production and processing. Appl Environ Microbiol 78:1853-1864

Keshri J, Y Chen, R Pinto, Y Kroupitski, ZG Weinberg, S Sela (2018). Microbiome dynamics during ensiling of corn with and without Lactobacillus plantarum inoculant. Appl Microbiol Biotechnol 102:4025-4037

Kleinschmit DH, JL Kung (2006). A meta-analysis of the effects of Lactobacillus buchneri on the fermentation and aerobic stability of corn and grass and small-grain silages. J Dairy Sci 89:4005-4013

Koc F, SO Aksoy, AA Okur, G Celikyurt, D Korucu, ML Ozduven (2017). Effect of pre-fermented juice, Lactobacillus plantarum and Lactobacillus buchneri on the fermentation characteristics and aerobic stability of high dry matter alfalfa bale silage. J Anim Plant Sci 27:1426-1431

Kung L, RE Muck (2015). Silage additives: Where are we going? In: International Silage Conference, pp: 72-81. University of Sao Paulo, Piracicaba, SP, Brazil

Larsen SU, K Hiort-Gregersen, AH Vazifehkhoran, JM Triolo (2017). Coensiling of straw with sugar beet leaves increases the methane yield from straw. Bioresour Technol 245:106-115

Li L, Y Sun, Z Yuan, X Kong, Y Wao, L Yang, Y Zhang, D Li (2015). Effect of microalgae supplementation on the silage quality and anaerobic digestion performance of Manyflower silvergrass. Bioresour Technol 189:334-340

Li Y, N Nishino (2011). Bacterial and fungal communities of wilted Italian ryegrass silage inoculated with and without Lactobacillus rhamnosus or Lactobacillus buchneri. Lett Appl Microbiol 52:314-321

Magoč T, SL Salzberg (2011). FLASH: fast length adjustment of short reads to improve genome assemblies. Bioinformatics 27:2957-2963

McDonald P, AR Henderson, SJE Heron (1991). The Biochemistry of Silage. Chalcombe Publications, Marlow, UK

Muck RE (2010). Silage microbiology and its control through additives. Rev Bras Zootecn 39:183-191

Muck RE, EMG Nadeau, TA Mcallister, FE Contreras-Govea, MC Santos, L Kung (2018). Silage review: Recent advances and future uses of silage additives. J Dairy Sci 101:3980-4000

Muck RE, ZG Weinberg, FE Contreras-Govea (2013). Silage extracts used to study the mode of action of silage inoculants in ruminants. Agric Food Sci 22:108-114

Murphy RP (1958). A method for the extraction of plant samples and the determination of total soluble carbohydrates. J Sci Food Agric 9:714-717

Ni K, F Wang, B Zhu, J Yang, G Zhou, Y Pan, Y Tao, J Zhong (2017). Effects of lactic acid bacteria and molasses additives on the microbial community and fermentation quality of soybean silage. Bioresour Technol 238:706-715
Oliveira AS, ZG Weinberg, IM Ogunade, AAP Cervantes, KG Arriola, Y Jiang, D Kim, X Li, MCM Goncalves, D Vyas, AT Adesogan (2017). Meta-analysis of effects of inoculation with homofermentative and facultative heterofermentative lactic acid bacteria on silage fermentation, aerobic stability, and the performance of dairy cows. J Dairy Sci 100:4587-4603

Pahlow G, RE Muck, F Driehuis, SJWHO Elferink, SF Spoelstra (2003). Microbiology of ensiling. In: Silage Science and Technology, Vol 42, pp: 31-93. Am. Soc. Agron., Crop Sci. Soc. Am., and Soil Sci. Soc. Am. (ASA, CSSA, and SSSA), Madison, Wisconsin, USA

Ridwan R,IRusmana, YWidyastuti, KG Wiryawan, B Prasetya, M Sakamoto, MOhkuma (2015). Fermentation characteristics and microbial diversity of tropical grass-legumes silages. Asian Aust J Anim 28:511-518

Rossi F, F Dellaglio (2007). Quality of silages from Italian farms as attested by number and identity of microbial indicators. J Appl Microbiol 103:1707-1715

Soest PJV, JB Robertson, BA Lewis (1991). Methods for dietary fiber, neutral detergent fiber, and nonstarch polysaccharides in relation to animal nutrition. J Dairy Sci 74:3583-3597

Stevenson DM, RE Muck, KJ Shinners, PJ Weimer (2006). Use of real time PCR to determine population profiles of individual species of lactic acid bacteria in alfalfa silage and stored corn stover. Appl Microbiol Biotechnol 71:329-338

Wang Q, GM Garrity, JM Tiedje, JR Cole (2007). Naïve bayesian classifier for rapid assignment of rRNA sequences into the new bacterial taxonomy. Appl Environ Microbiol 73:5261-5267

Wang Y, C Wang, W Zhou, FY Yang, XY Chen, Q Zhang (2018). Effects of wilting and Lactobacillus plantarum addition on the fermentation quality and microbial community of Moringa oleifera leaf silage. Front Microbiol 9; Article 1817

Weatherburn MW (1967). Phenol-hypochlorite reaction for determination of ammonia. Anal Chem 39:971-974

Weinberg ZG, G Ashbell, Y Hen, A Azrieli (1993). The effect of applying lactic acid bacteria at ensiling on the aerobic stability of silages. $J$ Appl Bacteriol 75:512-518

Woolford MK, G Pahlow (1984). The Silage Fermentation. Marcel Dekker Inc., New York, USA

Xu D, W Ding, W Ke, F Li, P Zhang, X Guo (2019). Modulation of metabolome and bacterial community in whole crop corn silage by inoculating homofermentative Lactobacillus plantarum and heterofermentative Lactobacillus buchneri. Front Microbiol 9; Article 3299

Zhang H, J Wu, L Gao, J Yu, X Yuan, W Zhu, X Wang, Z Cui (2018). Aerobic deterioration of corn stalk silage and its effect on methane production and microbial community dynamics in anaerobic digestion. Bioresour Technol 250:828-837

Zhang Q, X Li, M Zhao, Z Yu (2016). Lactic acid bacteria strains for enhancing the fermentation quality and aerobic stability of Leymus chinensis silage. Grass Forage Sci 71:472-481

Zhao X, J Liu, J Liu, F Yang, W Zhu, X Yuan, Y Hu, Z Cui, X Wang (2017). Effect of ensiling and silage additives on biogas production and microbial community dynamics during anaerobic digestion of switchgrass. Bioresour Technol 241:349-359 